\title{
Biogeochemical consequences of a changing Arctic shelf seafloor ecosystem
}

\author{
Christian März (1), Felipe S. Freitas, Johan C. Faust, \\ Jasmin A. Godbold, Sian F. Henley, Allyson C. Tessin, \\ Geoffrey D. Abbott, Ruth Airs, Sandra Arndt, David K. A. Barnes, \\ Laura J. Grange, Neil D. Gray, Ian M. Head, Katharine R. Hendry, \\ Robert G. Hilton, Adam J. Reed, Saskia Rühl, Martin Solan, \\ Terri A. Souster, Mark A. Stevenson, Karen Tait, \\ James Ward, Stephen Widdicombe
}

Received: 3 May 2021/Revised: 2 September 2021/Accepted: 22 September 2021/Published online: 9 October 2021

\begin{abstract}
Unprecedented and dramatic transformations are occurring in the Arctic in response to climate change, but academic, public, and political discourse has disproportionately focussed on the most visible and direct aspects of change, including sea ice melt, permafrost thaw, the fate of charismatic megafauna, and the expansion of fisheries. Such narratives disregard the importance of less visible and indirect processes and, in particular, miss the substantive contribution of the shelf seafloor in regulating nutrients and sequestering carbon. Here, we summarise the biogeochemical functioning of the Arctic shelf seafloor before considering how climate change and regional adjustments to human activities may alter its biogeochemical and ecological dynamics, including ecosystem function, carbon burial, or nutrient recycling. We highlight the importance of the Arctic benthic system in mitigating climatic and anthropogenic change and, with a focus on the Barents Sea, offer some observations and our perspectives on future management and policy.
\end{abstract}

Keywords Arctic Ocean · Biogeochemistry - Carbon · Ecology $\cdot$ Nutrients $\cdot$ Trawling

\section{INTRODUCTION}

The Arctic Ocean seafloor hosts a diverse and productive benthic ecosystem that is a crucial component of an intimately coupled benthic-pelagic system (Fig. 1; Piepenburg 2005). Benthic organisms modulate sequestration, transformation, and storage of bio-essential nutrients and carbon across the Arctic shelf seas (Morata et al. 2020). A significant proportion of organic matter (OM) from marine, terrestrial, or sea ice sources is further recycled via microbially mediated processes that are coupled to the activities of benthic meio-, macro-, and megafauna (e.g. via bioturbation, bioirrigation; Piepenburg et al. 1995; Renaud et al. 2008). These biological and biogeochemical processes partition the carbon and nutrient pools into a fraction that is recycled to drive a benthic-pelagic feedback loop, and a fraction that is buried in the sediment. On the shallow Arctic shelf, the feedback with water column processes (via physical mixing and primary productivity) is more pronounced than in the deep ocean and plays a crucial role for benthic-pelagic coupling and ecosystem productivity; the latter could then contribute to the long-term removal of carbon from the ocean-atmosphere system. Key uncertainties exist, however, in how changing sea ice dynamics (e.g. thickness, extent, inter-annual variability) will alter existing biological community composition and structure, biogeochemical processes, and associated ecosystem functioning. Understanding how these responses are manifest in the benthic environment, both directly and indirectly, is crucial to understanding the Arctic ecosystem as a whole and its importance at the larger scale (Macdonald et al. 2015).

One frequently debated proposition on Arctic change is that longer and more extensive open water conditions, especially across Arctic shelves, could lead to prolonged growing seasons and enhanced $\mathrm{CO}_{2}$ uptake by biomass (Arrigo and Van Dijken 2015; Slagstad et al. 2015). Eventually, this could result in a negative feedback on the $\mathrm{CO}_{2}$-induced greenhouse effect in the Arctic as more carbon is sequestered into the sediment. However, modelling the response of the Arctic Ocean carbon and nutrient cycles to reduced sea ice and its associated, and partly counteracting, effects (deeper light penetration, longer growth seasons, increased water column stratification, ocean acidification, warming), is difficult-partly due to an incomplete mechanistic understanding of the changing 


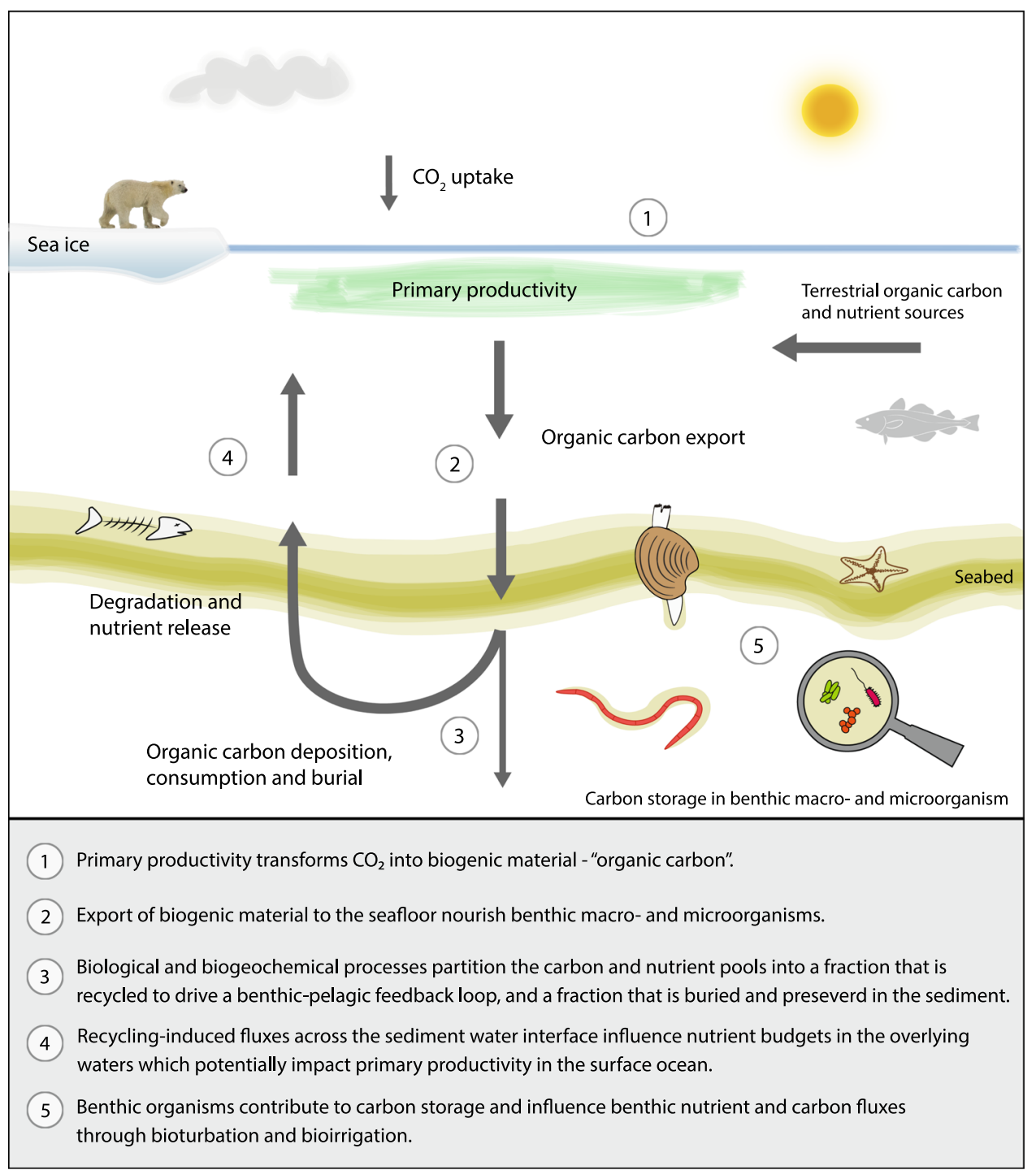

Fig. 1 Schematic illustration of ecological and biogeochemical parameters in Arctic Ocean shelf seas, with a focus on processes at the seafloor

Arctic Ocean seafloor. It is currently unclear which fraction of carbon and nutrients will be metabolised and transformed at the seafloor, which interactions between microbial and macro-benthic activity dominate these transformations, and what the effects are on ecosystem structure and functioning. Seafloor recycling likely plays a significant role for the whole Arctic Ocean, with associated societal feedbacks on fisheries and other marine resources, highlighting the critical importance of understanding and quantifying biogeochemical processes at the Arctic seafloor. The carbon storage potential of marine sediments in particular has only recently been recognised and evaluated (Luisetti et al. 2020). Aspects to consider here are the reliable knowledge of carbon contents, the vulnerability of this carbon store, and its assignment to specific nations. These questions will be relevant for designing governance frameworks on sediment carbon storage, but there is little empirical support to the assumed carbon inventory. Although sophisticated, multi-component diagenetic models now exist, most regional- to global-scale biogeochemical and Earth system models do not resolve the complexity of the seafloor environment. Moreover, models tend to neglect or simplify biogeochemical processes by using a limited number of parameters in the sediment and, in so doing, misrepresent organism-sediment interactions and benthic-pelagic coupling (Lessin et al. 2018; LaRowe et al. 2020).

With the recognition that the Arctic is undergoing transformative, and possibly irreversible, changes come a need to re-evaluate how external forcing could change the fundamentals of the system. For context, we describe the role of the Arctic Ocean seafloor in carbon and nutrient cycling, OM burial, and ecological function, provide context of how this role might change in the future, use a 
reaction-transport model to estimate possible changes to carbon and nutrient cycling in the Barents Sea, and give perspectives on human activities and management.

\section{BIOGEOCHEMICAL FUNCTIONING OF THE ARCTIC SHELF SEAFLOOR: RECYCLING VERSUS STORAGE}

Fundamentally, benthic recycling of carbon and nutrients is driven by the supply of biogenic material to the seafloor, and its subsequent degradation and dissolution (Fig. 1; e.g. Middelburg 2019). Rates of seafloor recycling are enhanced by intense activity of macro- and microorganisms, such as faunal feeding, sediment mixing, and microbial degradation. Recycling-induced fluxes across the sediment-water interface influence nutrient budgets in the overlying waters (e.g. Bourgeois et al. 2017), which, in turn, can impact primary production in the surface ocean. Any carbon that escapes benthic recycling gets preserved below the seafloor, and this carbon burial is crucial for transferring atmospheric $\mathrm{CO}_{2}$ to a long-term sediment store. It is this balance between benthic recycling and storage of carbon and nutrients that is likely to change in the future Arctic shelf seas.

In terms of carbon and nutrient cycling, Arctic shelf seas (e.g. the Barents Sea) are special because (i) they are often highly productive, with significant atmospheric $\mathrm{CO}_{2}$ uptake (Arrigo and van Dijken 2015); (ii) their shallow waters allow for a fast transfer of OM to the seafloor; and (iii) strong seasonality and cold temperatures allow for efficient, pulsed carbon transfer to the seafloor (Wassmann et al. 2006a, b; DeVries and Weber 2017). Once at the seafloor, the fate of carbon and nutrients depends on the quality and quantity of exported OM (Morata and Renaud 2008; Stevenson et al. 2020), the stability of sedimentary OM and nutrients linked to reactive iron phases in the upper sediments (Faust et al. 2020, 2021), and the composition and process rates of benthic biota (McTigue et al. 2016; Solan et al. 2020a, b). For the Barents Sea, recent models (Freitas et al. 2020) suggest that benthic recycling of nutrients from sediments to overlying waters is mainly controlled by OM reactivity, and therefore, its source, age, and total amount (Fig. 2). In addition, this study shows the magnitude of nutrient fluxes to be somewhat independent from sea ice extent and, instead, to be mostly impacted by the (physico-chemical) structure of the overlying waters (Freitas et al. 2020). With the pronounced changes in Arctic Ocean ecosystems (e.g. changes in sea ice, water masses, phytoplankton species) that are projected to intensify in the coming decades (e.g. Arthun et al. 2012; Smedsrud et al. 2013; Oziel et al. 2017, 2020; Lewis et al. 2020), the trajectory of carbon and nutrient recycling at the seafloor is uncertain.

\section{ALTERED SYSTEM EXPRESSIONS AND DYNAMICS}

Available evidence suggests that conditions across the Barents Sea, and other Arctic inflow shelves, will become more akin to those of sub-Arctic seas. Warming is predicted to promote Barents Sea 'Atlantification' and Chukchi Sea 'Pacification' whereby warmer, saltier, and nutrient-richer waters routinely expand further north, often leading to higher primary productivity (Barton et al. 2018; Lind et al. 2018). If sea ice reduction is paralleled by enhanced vertical mixing (Lind et al. 2018; Randelhoff et al. 2020), phytoplankton growing seasons are extended. Enhanced mixing and bloom duration could shift nutrient demands (Downes et al. 2021), with knock-on effects on carbon export. It should be noted, however, that due to the environmental complexities, there is significant uncertainty in any prediction of Arctic Ocean primary productivity (Vancoppenolle et al. 2013). In addition, thawing permafrost is now prevalent around the Arctic Ocean (in particular in Siberia) which, combined with higher river runoff, will deliver more carbon and nutrients to the Arctic shelves (e.g. Bröder et al. 2018; Terhaar et al. 2021). These changes in the status quo will likely alter pathways of carbon delivery to the seafloor and, in turn, the amount of carbon preserved within sediments. Further, changes in the composition and behaviour of the benthic community will affect the fate of both organic and inorganic carbon accumulation at the seafloor. While there is a basic understanding of current factors affecting Arctic seafloor biogeochemistry, some controls on $\mathrm{OM}$ burial play out over thousands of years (e.g. Faust et al. 2021). It is unknown if ongoing/future climate change may perturb these processes, either by modifying carbon inputs and/or the microbial communities and degradation pathways below the seafloor (Brüchert et al. 2018). In addition, while the burial of zoobenthic carbon may be more strongly affected by ecosystem change (i.e. the dominant benthic fauna), no clear link between this carbon pool and the position of the sea ice margin was found in the Barents Sea (Souster et al. 2020). This may be partly due to the limited number of habitats studied, or the numerous and complex interactions along the process chain from sea ice cover and carbon export to dynamic ecosystem responses. At similar water depths around Antarctica, across-habitat studies have suggested that maximum burial may occur in habitat interface zones, e.g. where basins meet glacial moraines (Barnes and Sands 2017).

Intimately linked to OM deposition at the seafloor is the cycling of nutrients. Benthic nutrient recycling rates and fluxes are highly sensitive to the impacts of primary production and OM export changes (e.g. Freitas et al. 2021). Extension of the phytoplankton growing season in the 


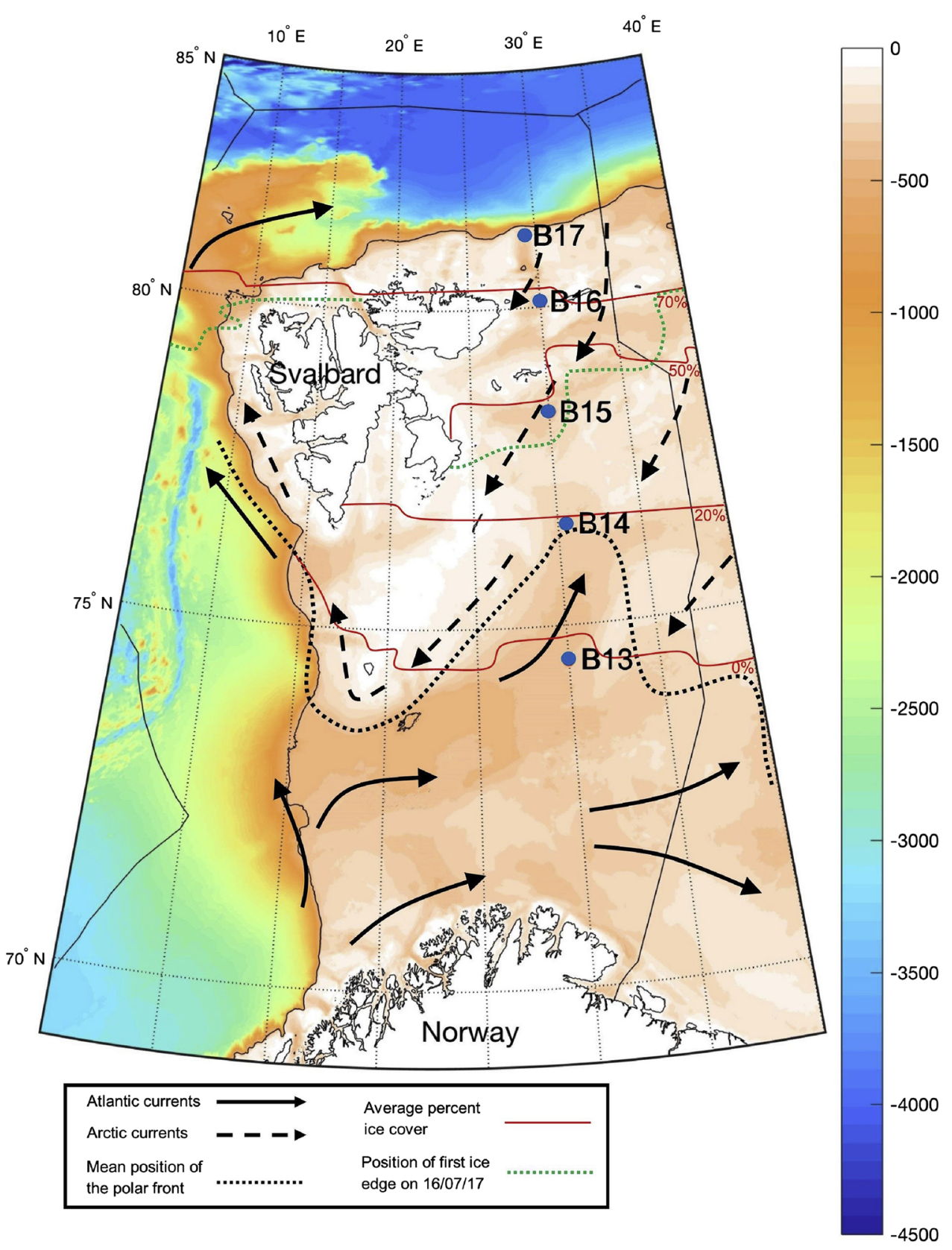

Fig. 2 Location of Barents Sea shelf stations B13-B17 sampled in July 2017. Bathymetric depth chart indicating metres below sea level (m.b.s.l.). Depths of sampling were $359 \mathrm{~m}$ at B13 (74 $\left.29.998 \mathrm{~N}, 30^{\circ} 00.009 \mathrm{E}\right), 293 \mathrm{~m}$ at B14 $\left(76^{\circ} 30.055 \mathrm{~N}, 30^{\circ} 30.241 \mathrm{E}\right), 317 \mathrm{~m}$ at B15 (78 $\left.15.100 \mathrm{~N}, 30^{\circ} 00.540 \mathrm{E}\right), 283 \mathrm{~m}$ at B16 ( $\left.80^{\circ} 07.154 \mathrm{~N}, 30^{\circ} 04.069 \mathrm{E}\right)$, and $340 \mathrm{~m}$ at B17 (81 $\left.16.765 \mathrm{~N}, 30^{\circ} 19.496 \mathrm{E}\right)$. From Stevenson and Abbott (2019)

Barents Sea carries with it the potential to increase total primary production if sufficient nutrients are available (e.g. Henley et al. 2020; Lewis et al. 2020). Should this occur, and translate into greater export of 'fresh' OM, it could lead to higher benthic nutrient fluxes, although any effect is unlikely to be universally expressed due to strong regional differences (e.g. Downes et al. 2020; Oziel et al. 2020). Indeed, the highly seasonal, often short-term, and highly regional benthic-pelagic dynamics on Arctic shelves go some way in explaining why an often assumed link between sea ice cover and benthic nutrient fluxes is not always found (Freitas et al. 2020). This contrasts with sediment carbon dynamics, with seasonally ice-covered parts of the Barents Sea exhibiting lower organic carbon contents, but higher organic carbon burial rates (Faust et al. 2020) and higher abundances of benthic fauna (Souster et al. 2020). On Arctic shelves and margins currently more permanently ice covered (e.g. Yermak Plateau), changes in 
primary production and $\mathrm{OM}$ delivery to the seafloor can lead to comparatively greater changes in benthic nutrient fluxes as compared to the low background values (Tessin et al. 2020).

While no systematic relationship between benthic nutrient fluxes and sea ice cover was found in the Barents Sea, there is a significant link with water mass distributions and 'Atlantification'. Benthic nutrient fluxes in summer 2017 were higher at stations dominated by Atlantic water (B13, B14, B17; Fig. 2) than at those dominated by Arctic water (B15, B16; Fig. 2) (Freitas et al 2020). If 'Atlantification' continues, benthic nutrient fluxes are likely to increase across the region, irrespective of superimposed seasonal and spatial variability. However, patterns of response will depend on the relative importance of, and interactions between, increased bottom water temperatures, changes in primary production and phytoplankton communities, and OM delivery to the seafloor. And since the benthic efflux depends on fixation of nutrients in deposited organic biomass, a net addition to benthic nutrient effluxes will only occur if the Barents Sea system as a whole receives increased external nutrients, for example, through Atlantic water (Oziel et al. 2017) or by increased input (and degradation) of terrestrial OM (Terhaar et al. 2019, 2021).

\section{ESTIMATING FUTURE ORGANIC CARBON BURIAL AND BENTHIC NUTRIENT CYCLING USING A REACTION-TRANSPORT MODEL}

Working from the realistic assumption (for reasons stated above) that reduced sea ice in the Barents Sea may lead to increased $\mathrm{OM}$ export to the seafloor, we estimate the impact of this on carbon burial and degradation rates by performing a simple model sensitivity analysis (Fig. 3). We use our baseline model for the Barents Sea shelf (Freitas et al. 2020) that is confounded in biogeochemical data from five key stations across the Polar Front in the summers of 2017-2019 (Fig. 2). Here, we test how relative fluctuations in OM input (1-3 times the baseline values; expressed as total organic carbon, TOC) to the seafloor translate into absolute and relative changes in burial and degradation rates. While an increase in $\mathrm{OM}$ export to the seafloor from primary productivity will impact $\mathrm{OM}$ degradation pathways, the impact on long-term sediment carbon burial will be minor, as phytoplankton OM is quickly degraded at the seafloor (Fig. 3). However, we also observe that the fraction of carbon preserved at depth is highest at stations B15 and B16 (just north of the Polar Front), for poorly known reasons but presumably related to the dominance of Arctic water and/or seasonal sea ice at those stations. How much of the carbon delivered into shelf seas by permafrost thaw, coastal erosion, and major river systems is degraded before burial is debated (e.g. Tank et al. 2012; Bröder et al. 2018, 2019; Brüchert et al. 2018;) and further complicated by lateral OM transport along the shelf (Stevenson et al. 2020). Nevertheless, terrestrial processes will likely exert a major control on OM quality/quantity by delivering less degradable OM to Barents Sea sediments (Freitas et al. 2020). Impacts of higher OM fluxes on zoobenthic carbon standing stocks are poorly studied in the Arctic but, in West Antarctic shelf seas, extended phytoplankton blooms promoted by sea ice loss have led to a doubling of zoobenthic carbon standing stock (Barnes 2015, 2017). It is tempting, therefore, to suggest that a similar development might occur on Arctic shelves.

In a second step, to estimate the impacts of OM export changes on benthic nutrient fluxes (ignoring ecological drivers), we expand a simple model sensitivity analysis used for TOC degradation and burial rates (after Freitas et al. 2020) to calculate benthic nutrient fluxes (nitrate, ammonium, phosphate; Fig. 4). We change the OM content to $0.1-6$ times relative to baseline values, keeping all other model parameters unchanged. Our simulation shows that any fluctuation in OM input to the seafloor will result in a concomitant adjustment in nutrient fluxes (Fig. 4), even though the responses are not strictly linear, vary between sites, and are nutrient-specific. Our results also suggest that absolute changes in nutrient fluxes are likely to be more pronounced at sites influenced by Atlantic Water, and that relative increases in $\mathrm{OM}$ input will trigger large changes in the way $\mathrm{OM}$ is being degraded at and below the seafloor. The relative contribution of aerobic OM degradation will decrease considerably as oxygen will become quickly depleted (Fig. 4), while anaerobic conditions will prevail in the upper end of OM addition scenarios.

It should be noted that changes to ecological factors were ignored in the modelling exercise above, but there is no doubt that environmental and anthropogenic change will also affect the benthic ecosystem. A faunal separation occurs between northern (Arctic) and southern (Atlantic) assemblages at the operational Polar Front (e.g. Jørgensen et al. 2015). The distribution of functionally important species has received some attention (Degen and Faulwetter 2019), but there are few direct measurements of faunal activity or physiological state, and no regional-scale assessments of the faunal mediation of biogeochemistry (Solan et al. 2019). Nevertheless, recent observations in the Barents Sea indicate that spatial and temporal variability in environmental setting will be important in explaining biodiversity and ecological functions at larger scales, more so than localised sea ice changes (Solan et al. 2020a, b; Souster et al. 2020; Oleszczuk et al. 2021). Changes in the quality and quantity of OM reaching the seabed can have significant implications for faunal physiology, behaviour, growth (Reed et al. 2021a), and reproduction (Reed et al. 2021b) and, in turn, 


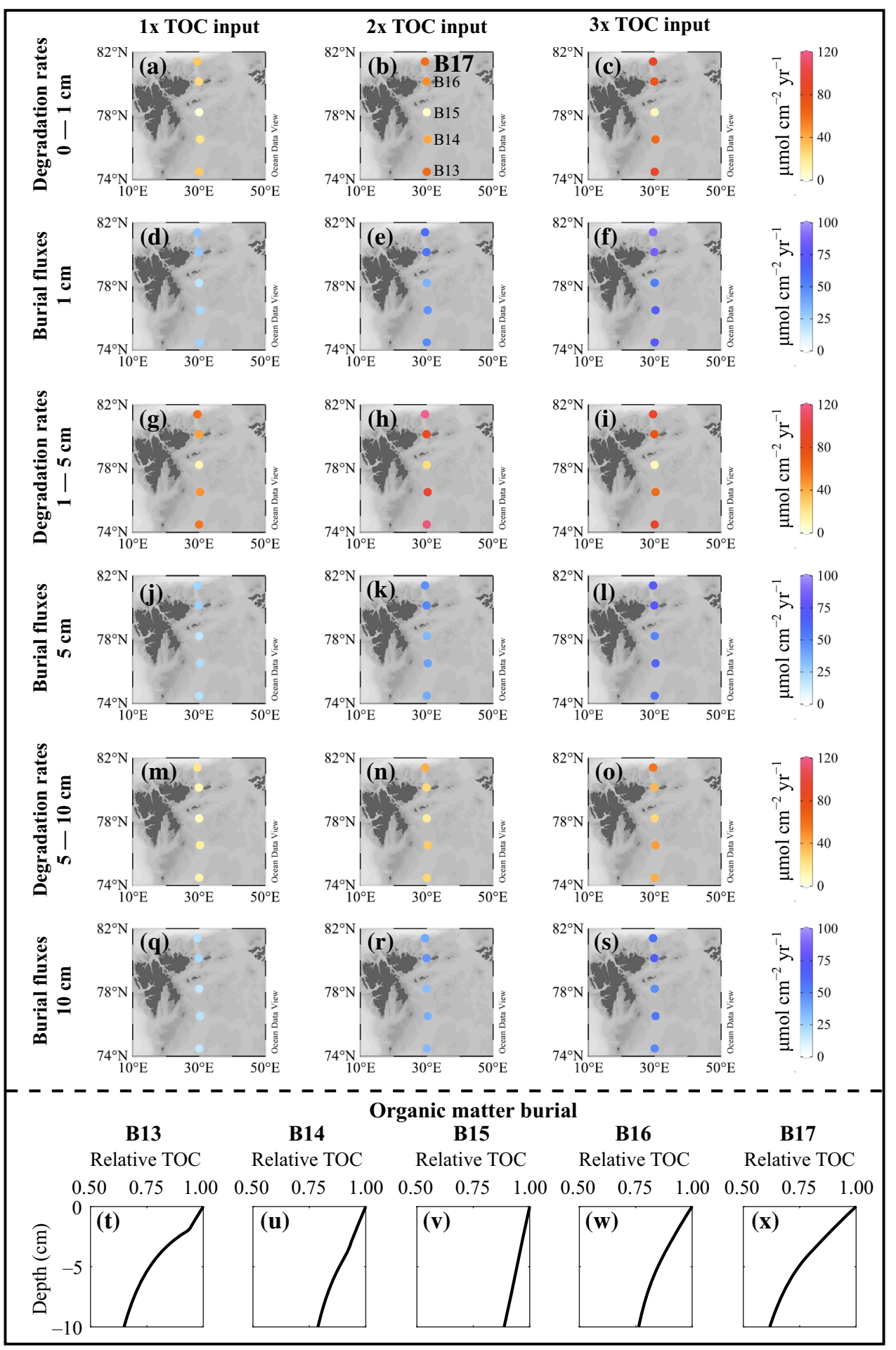

Fig. 3 Changes in degradation and burial rates of total organic carbon (TOC) following increased OM export to the seafloor at the Barents Sea sites B13-B17. Model adopted from Freitas et al. (2020), with outputs based on data gathered in July 2017. Integrated TOC degradation rates (warm colour bar) are shown for intervals a-c $0-1 \mathrm{~cm}, \mathbf{g}-\mathbf{i} 1-5 \mathrm{~cm}$, and $\mathbf{m}-\mathbf{o} 5-10 \mathrm{~cm}$ sediment depth. Corresponding TOC burial rates (cold colour bar) are shown at $\mathbf{d}-\mathbf{f} \mathbf{1}, \mathbf{j}-\mathbf{l} \mathbf{5}$, and $\mathbf{q}-\mathbf{s} 10 \mathrm{~cm}$ sediment depth. $\mathbf{t}-\mathbf{x}$ Relative fraction of TOC burial with increasing burial depth (cm) in response to input at sediment surface 


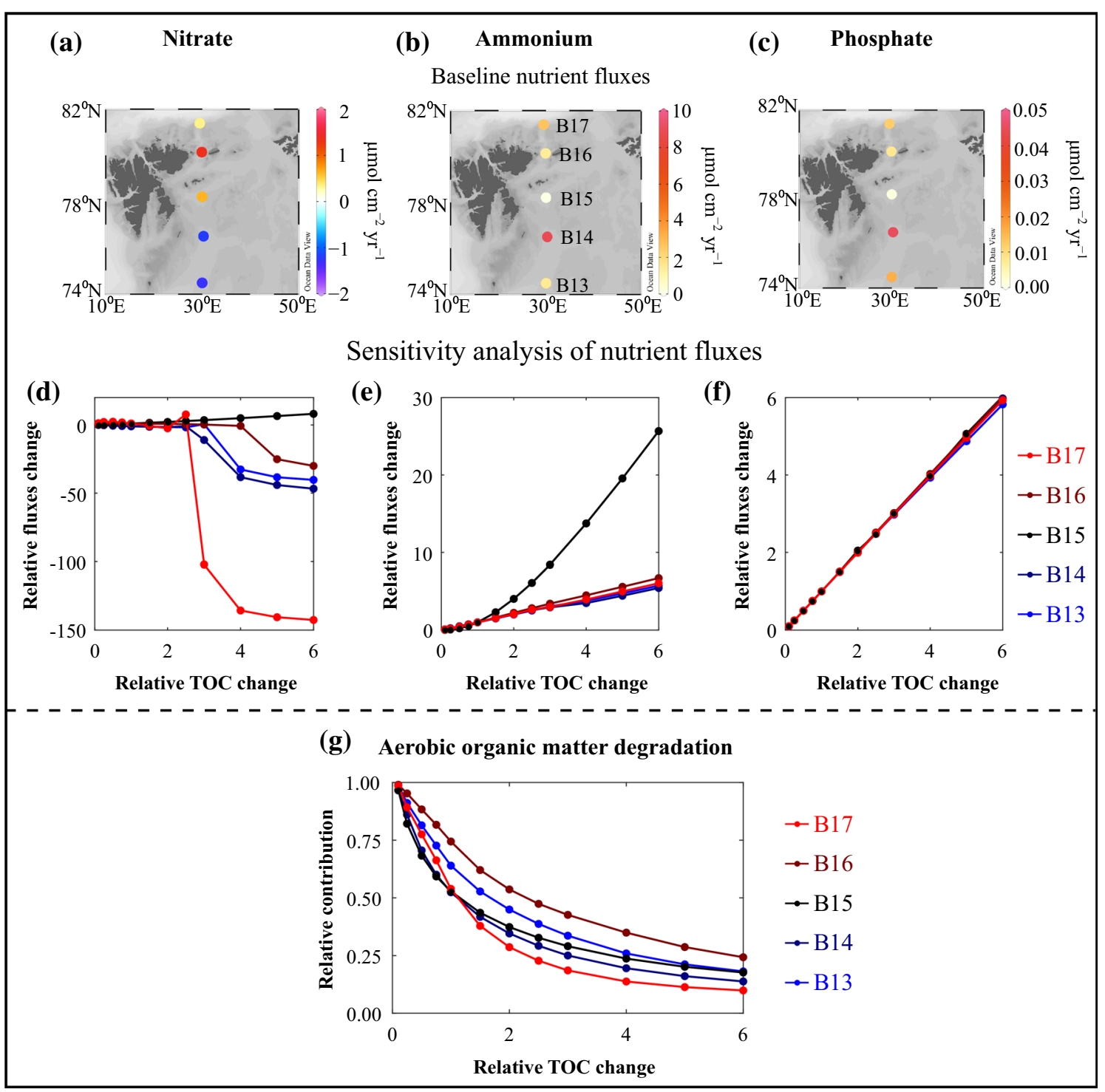

Fig. 4 Changes in biogeochemical parameters following increases in OM export to the seafloor at the Barents Sea sites B13-B17. Model adopted from Freitas et al. (2020), with outputs based on data gathered in July 2017. Top row: baseline nutrient fluxes of a nitrate, $\mathbf{b}$ ammonium, and $\mathbf{c}$ phosphate. Note the different scales in the colour bar and direction of fluxes: cold colours denote fluxes into sediments; warm colours denote fluxes out of the sediment. Middle row: changes in nutrient fluxes of $\mathbf{d}$ nitrate, $\mathbf{e}$ ammonium, and $\mathbf{f}$ phosphate relative to increased OM input. Note different scales in relative flux changes ( $y$-axis) due to nutrient-specific response to OM input and transformation at the seafloor: $\mathbf{d}$ nitrate fluxes become negative (i.e. sediments acting as nitrate sink rather than source), while $\mathbf{e}$ ammonium and $\mathbf{f}$ phosphate fluxes increase. Line colours $\mathbf{d}-\mathbf{g}$ denote reference sites in the Barents Sea. Bottom row: $\mathbf{g}$ changes in relative contribution of aerobic (presence of oxygen) OM degradation with gradual increase in OM input. Contribution of aerobic OM degradation decreases exponentially with higher OM input, which slows down overall degradation of $\mathrm{OM}$

biogeochemical cycling (Solan et al. 2020a, b). Overall, however, there is a clear south-north increase in species richness, biomass, and functional diversity of mega- and macro-zoobenthos, but the mixed depth of sediment and bioturbating activity of the community both decline with increasing latitude (Solan et al. 2020a, b; Souster et al. 2020).

\section{CLIMATE- AND HUMAN-INDUCED CHANGES}

The preservation of carbon within shelf sediments and benthic marine communities is likely to be altered by the expansion of human activities as sea ice retreats, including fishing, shipping, and petroleum exploration. With less challenging sea ice conditions and the northward migration of economically valuable fish stocks (e.g. Atlantic cod Gadus morhua, Greenland halibut Reinhardtuis 
hippoglossoides, shrimp Pandalus borealis), commercial fisheries follow and start trawling some of the last unfished areas of the global shelf seafloor. Bottom trawling causes re-working and re-suspension of seafloor sediment (Puig et al. 2012; O'Neill and Ivanović 2016), which can lead to erosion and perturbations to benthic biogeochemistry, in particular a loss of sedimentary organic carbon (Paradis et al. 2021). However, in the Barents Sea, reactive OM is quickly degraded and recycled to $\mathrm{CO}_{2}$ within the surface sediments (Freitas et al. 2020; Stevenson et al. 2020), even without human intervention. The question then arises as to whether trawling will impact the more stable, deeper, predegraded carbon stocks that remain in the sediments. This will depend on various factors, including the depth of trawl penetration (typically $10 \mathrm{~s}$ of $\mathrm{cm}$ ) and the overall sediment accumulation rates ( 4-200 cm/1000 years; Faust et al 2020): Under high sedimentation rates, reactive OM is buried relatively quickly, and re-exposure by trawling would negatively affecting overall carbon burial efficiency. In low sedimentation rate areas, trawling might have less of an effect on long-term carbon storage. Similar considerations can be made for nutrient recycling to the water column by the mechanical disturbance of sediments (Duplisea et al. 2001): if the disturbance reaches anaerobic layers where nutrient concentrations are significantly higher than in the overlying waters, the resulting enhanced nutrient fluxes can fuel additional pelagic primary production (Dounas et al. 2007; van der Velde et al. 2018; Tiano et al. 2021). Finally, the persistence of any trawling-induced disturbance in the Barents Sea would depend on type and frequency of trawling as well as primary productivity and sedimentation rates, but literature-based estimates range from several year to several decades (Buhl-Mortensen et al. 2016; Paradis et al. 2021).

Besides the sediment, polar benthic marine communities also store considerable carbon in the form of biota. Zoobenthic carbon in the Barents Sea is comparable to the highest levels in Antarctic shelf sediments (Souster et al. 2020). Changes in the density, diversity, and composition of mega-benthic communities associated with bottom fishing activity in the Barents Sea have been observed (Buhl-Mortensen et al. 2016) and can significantly affect the biomass and stored carbon of all species (Jørgensen et al. 2016).

\section{IMPLICATIONS FOR MANAGEMENT AND POLICY}

Warming, in combination with increased disturbance of the Arctic shelf seafloor, is already imposing significant changes to carbon and nutrient cycles, as well as ecosystems. Following scientific recommendation, areas with fishing restrictions or closure in the Barents Sea, particularly around Svalbard, were recently expanded by the Norwegian government (Jørgensen et al. 2020). The ecosystem protection afforded by MPA or similar protection status increased the likelihood of safeguarding carbon stocks and the processes that control seafloor carbon sequestration (Atwood et al. 2020; Sala et al. 2021). For example, modifying fishing gears, limiting or preventing seafloor trawling would reduce the physical disturbance that alters community composition and diversity, biogeochemical cycling, and the amount of carbon released back into the water (Duplisea et al. 2001; Dounas et al. 2007; Tiano et al. 2019). However, expansion of fishery exclusion zones in the Barents Sea is based largely on ecological/biodiversity criteria, rather than on the need for protecting carbon stocks (Jørgensen et al. 2020). Recognition of the carbon burial aspect of marine ecosystem services is currently missing in Arctic seas, but is increasingly recognised elsewhere (Atwood et al. 2020; Luisetti et al. 2020; Sala et al. 2021). Biologically rich, vulnerable marine environment hotspots can also be effective carbon sinks, as in the case of the first high seas MPA around the South Orkney Islands, Antarctic Peninsula (Trathan et al. 2014; Barnes et al 2016). Consideration of both nature and its functionality (ecosystem services or nature-based solutions, Solan et al. 2020a, b) provides a stronger and more comprehensive approach compared to a focus on biodiversity alone (e.g. Sala et al. 2021). Societal and scientific pressure has recently resulted in creation of some Very Large Marine-Protected Areas (VLMPAs) but, as Sala et al. (2021) note, this includes few areas within the polar regions. The polar regions have more governance complexity than most Exclusive Economic Zones (EEZs), but they lag behind global MPA creation, even though they could present new opportunities for carbon store protection. For example, 99\% of most of Ascension Island's VLMPA is deeper than $1000 \mathrm{~m}$, but the main carbon pathway to sequestration may occur in the shallowest $1000 \mathrm{~m}$ (Barnes et al. 2019). Protection of this shallow seabed safeguards $£ 1-2$ million of carbon capture to sequestration at UN shadow price of carbon estimates. There are opportunities in the Arctic to target such shallow carbon burial grounds. It is crucial to learn lessons from rushed MPA designations, since those are often agreed on economically unattractive areas, or implemented with clauses that allow resource exploitation to continue.

Society has to decide the type, rate and level of human activity that is acceptable in Arctic regions, while balancing competing demands and world views, and to agree on equitable ways to resolve conflict and maximise win-win strategies. However, the data needed to support effective marine management within the Arctic are sparse, incomplete or poorly quantified, making planning and more 
informed decision-making challenging. Even in the better investigated regions such as the Barents Sea, only parts of the carbon pathway (from capture to sequestration) are quantified and-even then-only for some habitats (e.g. muddy glacial troughs; Faust et al. 2020; Freitas et al. 2020; Solan et al. 2020a, b; Souster et al. 2020; Stevenson et al. 2020). When appropriate socio-ecological data do exist, the focus is spatially constrained and in a limited number of areas (Falardeau and Bennett 2020). However, we understand enough to know that vulnerable marine ecosystems on Arctic continental shelves are not necessarily co-located with the main carbon burial environments. The most productive and most heavily fished ecosystems are situated on shoals, around the coasts and above rocky ground, while most organic carbon is likely sequestered in muddy sediments of glacial troughs. We also know that high productivity and throughput of carbon do not necessarily mean high carbon sequestration. The prevailing systems controlling the cycling and storage of carbon in the Arctic seafloor are complex, and there is a general paucity of fully comprehensive datasets. Despite the challenges, it is possible to make considerable progress in identifying the most significant unprotected carbon burial hotspots, allowing for an effective assessment of the landscape of potential threats and the risks and rewards surrounding seafloor protection. Most ecosystems affected by human disturbance can recover when conditions improve, for example, if appropriate conservation measures are enacted and human pressure is managed (Jones and Schmitz 2009). To continue to benefit from seafloor carbon sinks and buy more time against climate change, we contend that MPAs (no bottom fishing) for newly exposed ice-free regions in the Arctic will be beneficial.

Acknowledgements We thank the crew and participants of cruises JR16006, JR17007, and JR18006, RRS James Clark Ross, administrative and technical personnel that conducted analyses, and National Marine Facilities, Southampton and the British Antarctic Survey, Cambridge for logistical support. We are grateful to members and facilitators of the Changing Arctic Ocean Programme and the Nansen LEGACY Project for sharing findings and experiences. Supported by 'The Changing Arctic Ocean Seafloor (ChAOS)' Project (NE/ N015894/1, 2017-2021), jointly funded by the Natural Environment Research Council (NERC) in the UK and the German Federal Ministry of Education and Research (BMBF). We also thank two anonymous reviewers and Guest Editor David Thomas for their comments which significantly improved the manuscript.

Open Access This article is licensed under a Creative Commons Attribution 4.0 International License, which permits use, sharing, adaptation, distribution and reproduction in any medium or format, as long as you give appropriate credit to the original author(s) and the source, provide a link to the Creative Commons licence, and indicate if changes were made. The images or other third party material in this article are included in the article's Creative Commons licence, unless indicated otherwise in a credit line to the material. If material is not included in the article's Creative Commons licence and your intended use is not permitted by statutory regulation or exceeds the permitted use, you will need to obtain permission directly from the copyright holder. To view a copy of this licence, visit http://creativecommons. org/licenses/by/4.0/.

\section{REFERENCES}

Arrigo, K.R., and G.L. van Dijken. 2015. Continued increases in Arctic Ocean primary productivity. Progress in Oceanography 136: 60-70. https://doi.org/10.1016/j.pocean.2015.05.002.

Årthun, M., T. Eldevik, L.H. Smedsrud, Ø. Skagseth, and R.B. Ingvaldsen. 2012. Quantifying the influence of Atlantic heat on Barents Sea ice variability and retreat. Journal of Climate 25: 4736-4743. https://doi.org/10.1175/JCLI-D-11-00466.1.

Atwood, T.B., A. Witt, J. Mayorga, E. Hammill, and E. Sala. 2020. Global patterns in marine sediment. Frontiers in Marine Science 7: 165. https://doi.org/10.3389/fmars.2020.00165.

Barnes, D.K.A. 2015. Antarctic sea ice losses drive gains in benthic carbon drawdown. Current Biology 25: R789-R790. https://doi. org/10.1016/j.cub.2015.07.042.

Barnes, D.K.A. 2017. Polar zoobenthos blue carbon storage increases with sea ice losses, because across-shelf growth gains from longer algal blooms outweigh ice scour mortality in the shallows. Global Change Biology 23: 5083-5091. https://doi.org/10.1111/ gcb.13772.

Barnes, D.K.A., and C.J. Sands. 2017. Functional group diversity is key to Southern Ocean benthic carbon pathways. Edited by Carlo Nike Bianchi. PLoS ONE 12: e0179735. https://doi.org/10.1371/ journal.pone.0179735.

Barnes, D.K.A., L. Ireland, O.T. Hogg, S. Morley, P. Enderlein, and C.J. Sands. 2016. Why is the South Orkney Island shelf (the world's first high seas marine protected area) a carbon immobilization hotspot? Global Change Biology 22: 1110-1120. https://doi.org/10.1111/gcb.13157.

Barnes, D.K.A., C.J. Sands, A. Richardson, and N. Smith. 2019. Extremes in benthic ecosystem services; blue carbon natural capital shallower than $1000 \mathrm{~m}$ in isolated, small, and young Ascension Island's EEZ. Frontiers in Marine Science. https:// doi.org/10.3389/fmars.2019.00663.

Barton, B.I., Y.-D. Lenn, and C. Lique. 2018. Observed Atlantification of the Barents Sea causes the Polar Front to limit the expansion of winter sea ice. Journal of Physical Oceanography 48: 1849-1866. https://doi.org/10.1175/JPO-D-18-0003.1.

Bourgeois, S., P. Archambault, and U. Witte. 2017. Organic matter remineralization in marine sediments: A Pan-Arctic synthesis. Global Biogeochemical Cycles 31: 190-213. https://doi.org/10. 1002/2016GB005378.

Bröder, L., T. Tesi, A. Andersson, I. Semiletov, and Ö. Gustafsson. 2018. Bounding cross-shelf transport time and degradation in Siberian-Arctic land-ocean carbon transfer. Nature Communications 9: 806. https://doi.org/10.1038/s41467-018-03192-1.

Bröder, L., A. Andersson, T. Tesi, I. Semiletov, and Ö. Gustafsson. 2019. Quantitative degradation loss of terrigenous organic carbon in surface sediments across the Laptev and East Siberian Sea. Global Biogeochemical Cycles 33: 85-99. https://doi.org/ 10.1029/2018GB005967.

Brüchert, V., L. Bröder, J.E. Sawicka, T. Tesi, S.P. Joye, X. Sun, I. Semiletov, and V.A. Samarkin. 2018. Carbon mineralization in Laptev and East Siberian Sea shelf and slope sediments. Biogeosciences 15: 471-490. https://doi.org/10.5194/bg-4712018.

Buhl-Mortensen, L., K.E. Ellingsen, P. Buhl-Mortensen, K.L. Skaar, and G. Gonzalez-Mirelis. 2016. Trawling disturbance on 
megabenthos and sediment in the Barents Sea: Chronic effects on density, diversity, and composition. ICES Journal of Marine Science 73: i98-i114. https://doi.org/10.1093/icesjms/fsv200.

Degen, R., and S. Faulwetter. 2019. The Arctic Traits Database-A repository of Arctic benthic invertebrate traits. Earth System Science Data 11: 301-322. https://doi.org/10.5194/essd-11-3012019.

DeVries, T., and T. Weber. 2017. The export and fate of organic matter in the ocean: New constraints from combining satellite and oceanographic tracer observations. Global Biogeochemical Cycles 31: 535-555. https://doi.org/10.1002/2016GB005551.

Dounas, C., I. Davies, G. Triantafyllou, P. Koulouri, G. Petihakis, C. Arvanitidis, G. Sourlatzis, and A. Eleftheriou. 2007. Large-scale impacts of bottom trawling on shelf primary productivity. Continental Shelf Research 27: 2198-2210.

Downes, P.P., S.J. Goult, E.M.S. Woodward, C.E. Widdicombe, K. Tait, and J.L. Dixon. 2020. Phosphorus dynamics in the Barents Sea. Limnology and Oceanography. https://doi.org/10.1002/lno. 11602.

Duplisea, D.E., S. Jennings, S.J. Malcolm, R. Parker, and D.B. Sivyer. 2001. Modelling potential impacts of bottom trawl fisheries on soft sediment biogeochemistry in the North Sea. Geochemical Transactions 2: 1-6.

Falardeau, M., and E.M. Bennett. 2020. Towards integrated knowledge of climate change in Arctic marine systems: A systematic literature review of multidisciplinary research. Arctic Science 6: 1-23. https://doi.org/10.1139/as-2019-0006.

Faust, J.C., M.A. Stevenson, G.D. Abbott, J. Knies, A. Tessin, I. Mannion, A. Ford, R. Hilton, et al. 2020. Does Arctic warming reduce preservation of organic matter in Barents Sea sediments? Philosophical Transactions of the Royal Society A: Mathematical, Physical and Engineering Sciences 378: 20190364. https:// doi.org/10.1098/rsta.2019.0364.

Faust, J.C., A. Tessin, B.J. Fisher, M. Zindorf, S. Papadaki, K.R. Hendry, K.A. Doyle, and C. März. 2021. Millennial scale persistence of organic carbon bound to iron in Arctic marine sediments. Nature Communications 12: 275. https://doi.org/10. 1038/s41467-020-20550-0.

Freitas, F.S., K.R. Hendry, S.F. Henley, J.C. Faust, A.C. Tessin, M.A. Stevenson, G.D. Abbott, C. März, and S. Arndt. 2020. Benthicpelagic coupling in the Barents Sea: An integrated data-model framework. Philosophical Transactions of the Royal Society A: Mathematical, Physical and Engineering Sciences 378: 20199359. https://doi.org/10.1098/rsta.2019.0359.

Freitas, F.S., P.A. Pika, S. Kasten, B.B. Jørgensen, J. Rassmann, C. Rabouille, S. Thomas, H. Sass, R.D. Pancost, and S. Arndt. 2021. New insights into large-scale trends of apparent organic matter reactivity in marine sediments and patterns of benthic carbon transformation. Biogeosciences 18: 4651-4679. https://doi.org/ 10.5194/bg-18-4651-2021.

Henley, S.F., E.L. Cavan, S.E. Fawcett, R. Kerr, T. Monteiro, R.M. Sherrell, A.R. Bowie, P.W. Boyd, et al. 2020. Changing biogeochemistry of the Southern Ocean and its ecosystem implications. Frontiers in Marine Science. https://doi.org/10. 3389/fmars.2020.00581.

Jones, H.P., and O.J. Schmitz. 2009. Rapid recovery of damaged ecosystems. Edited by Geoffrey Clayton Trussell. PLOS ONE 4: e5653. https://doi.org/10.1371/journal.pone.0005653.

Jørgensen, L.L., P. Ljubin, H.R. Skjoldal, R.B. Ingvaldsen, N. Anisimova, and I. M. . 2015. Distribution of benthic megafauna in the Barents Sea: Baseline for an ecosystem approach to management. ICES Journal of Marine Science 72: 595-613.

Jørgensen, L.L., B. Planque, T.H. Thangstad, and G. Certain. 2016. Vulnerability of megabenthic species to trawling in the Barents Sea. ICES Journal of Marine Science 73: i84-i97. https://doi. org/10.1093/icesjms/fsv107.
Jørgensen, L.L., G. Bakke, and A.H. Hoelb. 2020. Responding to global warming: New fisheries management measures in the Arctic. Progress in Oceanography 188: 102423. https://doi.org/ 10.1016/j.pocean.2020.102423.

LaRowe, D.E., S. Arndt, J.A. Bradley, E.R. Estes, A. Hoarfrost, S.Q. Lang, K.G. Lloyd, N. Mahmoudi, et al. 2020. The fate of organic carbon in marine sediments-New insights from recent data and analysis. Earth-Science Reviews 204: 103146. https://doi.org/10. 1016/j.earscirev.2020.103146.

Lessin, G., Y. Artioli, E. Almroth-Rosell, J.C. Blackford, A.W. Dale, R.N. Glud, J.J. Middelburg, R. Pastres, et al. 2018. Modelling marine sediment biogeochemistry: Current knowledge gaps, challenges, and some methodological advice for advancement. Frontiers in Marine Science 5: 19. https://doi.org/10.3389/fmars. 2018.00019.

Lewis, K.M., G.L. van Dijken, and K.R. Arrigo. 2020. Changes in phytoplankton concentration now drive increased Arctic Ocean primary production. Science 369: 198-202. https://doi.org/10. 1126/science.aay8380.

Lind, S., R.B. Ingvaldsen, and T. Furevik. 2018. Arctic warming hotspot in the northern Barents Sea linked to declining sea-ice import. Nature Climate Change 8: 634-639. https://doi.org/10. 1038/s41558-018-0205-y.

Luisetti, T., S. Ferrini, G. Grilli, T.D. Jickells, H. Kennedy, S. Kröger, I. Lorenzoni, B. Milligan, et al. 2020. Climate action requires new accounting guidance and governance frameworks to manage carbon in shelf seas. Nature Communications 11: 4599. https:// doi.org/10.1038/s41467-020-18242-w.

Macdonald, R.W., Z.Z. Kuzyk, and S.C. Johannesson. 2015. The vulnerability of Arctic shelf sediments to climate change. Environmental Reviews. https://doi.org/10.1139/er-2015-0040.

McTigue, N.D., W.S. Gardner, K.H. Dunton, and A.K. Hardison. 2016. Biotic and abiotic controls on co-occurring nitrogen cycling processes in shallow Arctic shelf sediments. Nature Communications 7: 13145. https://doi.org/10.1038/ncomms13145.

Middelburg, J.J. 2019. Marine carbon biogeochemistry—A primer for earth system scientists. Springer briefs in earth system sciences. Cham: Springer. https://doi.org/10.1007/978-3-030-10822-9.

Morata, N., and P.E. Renaud. 2008. Sedimentary pigments in the western Barents Sea: A reflection of pelagic-benthic coupling? Studies in Oceanography 55: 2381-2389. https://doi.org/10. 1016/j.dsr2.2008.05.004.

Morata, N., E. Michaud, M.-A. Poullaouec, J. Devesa, M. Le Goff, R. Corvaisier, and P.E. Renaud. 2020. Climate change and diminishing seasonality in Arctic benthic processes. Philosophical Transactions of the Royal Society A: Mathematical, Physical and Engineering Sciences. https://doi.org/10.1098/rsta.2019.0369.

O'Neill, F.G., and A. Ivanović. 2016. The physical impact of towed demersal fishing gears on soft sediments. ICES Journal of Marine Science 73: i5-i14. https://doi.org/10.1093/icesjms/ fsv125.

Oleszczuk, B., K. Grzelak, and M. Kędra. 2021. Community structure and productivity of Arctic benthic fauna across depth gradients during springtime. Deep Sea Research I 170: 103457. https://doi. org/10.1016/j.dsr.2020.103457.

Oziel, L., G. Neukermans, M. Ardyna, C. Lancelot, J.-L. Tison, P. Wassmann, J. Sirven, D. Ruiz-Pino, and J.-C. Gascard. 2017. Role for Atlantic inflows and sea ice loss on shifting phytoplankton blooms in the Barents Sea. Journal of Geophysical Research: Oceans 122: 5121-5139. https://doi.org/10.1002/ 2016JC012582.

Oziel, L., A. Baudena, M. Ardyna, P. Massicotte, A. Randelhoff, J.-B. Sallée, R.B. Ingvaldsen, E. Devred, and M. Babin. 2020. Faster Atlantic currents drive poleward expansion of temperate phytoplankton in the Arctic Ocean. Nature Communications 11: 1705. https://doi.org/10.1038/s41467-020-15485-5. 
Paradis, S., M. Goñi, P. Masqué, R. Durán, M. Arjona-Camas, A. Palanques, and P. Puig. 2021. Persistence of biogeochemical alterations of deep-sea sediments by bottom trawling. Geophysical Research Letters. https://doi.org/10.1029/2020GL091279.

Piepenburg, D., T.H. Blackburn, C.F. von Dorrien, J. Gutt, P. O. J. Hall, S. Hulth, M. A. Kendall, K. W. Opalinski, E. Rachor, and M. K. Schmid. 1995. Partitioning of benthic community respiration in the Arctic (northwestern Barents Sea). Marine Ecology Progress Series 118: 199-213.

Piepenburg, D. 2005. Recent research on Arctic benthos: Common notions need to be revised. Polar Biology 28: 733-755.

Polyakov, I.V., A.V. Pnyushkov, M.B. Alkire, I.M. Ashik, T.M. Baumann, E.C. Carmack, I. Goszczko, J. Guthrie, et al. 2017. Greater role for Atlantic inflows on sea-ice loss in the Eurasian Basin of the Arctic Ocean. Science 356: 285-291. https://doi.org/ 10.1126/science.aai8204.

Puig, P., M. Canals, J.B. Company, J. Martín, D. Amblas, G. Lastras, A. Palanques, and A.M. Calafat. 2012. Ploughing the deep sea floor. Nature 489: 286-289.

Randelhoff, A., J. Holding, M. Janout, M.K. Sejr, M. Babin, J.-É. Tremblay, and M.B. Alkire. 2020. Pan-Arctic Ocean primary production constrained by turbulent nitrate fluxes. Frontiers in Marine Science. https://doi.org/10.3389/fmars.2020.00150.

Reed, A.J., J.A. Godbold, L.J. Grange, and M. Solan. 2021a. Growth of marine ectotherms is regionally constrained and asymmetric with latitude. Global Ecology and Biogeography 30: 578-589. https://doi.org/10.1111/geb.13245.

Reed, A.J., J.A. Godbold, M. Solan, and L.J. Grange. 2021b. Reproductive traits and population dynamics of benthic invertebrates indicate episodic recruitment patterns across an Arctic Polar Front. Ecology and Evolution. https://doi.org/10.1002/ ece3.7539.

Renaud, P.E., N. Morata, M. Carroll, S.G. Denisenko, and M. Reigstad. 2008. Pelagic-benthic coupling in the western Barents Sea: Processes and time scales. Deep-Sea Research II 55: 2372-2380.

Sala, E., J. Mayorga, D. Bradley, R.B. Cabral, T.B. Atwood, A. Auber, W. Cheung, C. Costello, et al. 2021. Protecting the global ocean for biodiversity, food and climate. Nature 592: 397-402. https://doi.org/10.1038/s41586-021-03371-z.

Slagstad, D., P.F.J. Wassmann, and I. Ellingsen. 2015. Physical constrains and productivity in the future Arctic Ocean. Frontiers in Marine Science 2: 85.

Smedsrud, L.H., I. Esau, R.B. Ingvaldsen, T. Eldevik, P.M. Haugan, C. Li, V.S. Lien, A. Olsen, et al. 2013. The role of the Barents Sea in the Arctic climate system. Reviews of Geophysics 51: $415-449$.

Solan, M., E.R. Ward, E.L. White, E.E. Hibberd, C. Cassidy, J.M. Schuster, R. Hale, and J.A. Godbold. 2019. Worldwide measurements of bioturbation intensity, ventilation rate, and the mixing depth of marine sediments. Scientific Data 6: 58. https:// doi.org/10.1038/s41597-019-0069-7.

Solan, M., E.M. Bennett, P.J. Mumby, J. Leyland, and J.A. Godbold. 2020a. Benthic-based contributions to climate change mitigation and adaptation. Philosophical Transactions of the Royal Society B: Biological Sciences 375: 20190107. https://doi.org/10.1098/ rstb.2019.0107.

Solan, M., E.R. Ward, C.L. Wood, A.J. Reed, L.J. Grange, and J.A. Godbold. 2020b. Climate-driven benthic invertebrate activity and biogeochemical functioning across the Barents Sea Polar Front. Philosophical Transactions of the Royal Society A: Mathematical, Physical and Engineering Sciences 378: 20190365. https://doi.org/10.1098/rsta.2019.0365.

Souster, T.A., D.K.A. Barnes, and J. Hopkins. 2020. Variation in zoobenthic blue carbon in the Arctic's Barents Sea shelf sediments. Philosophical Transactions of the Royal Society A:
Mathematical, Physical and Engineering Sciences 378: 20190362. https://doi.org/10.1098/rsta.2019.0362.

Stevenson, M.A., and G.D. Abbott. 2019. Exploring the composition of macromolecular organic matter in Arctic Ocean sediments under a changing sea ice gradient. Journal of Analytical and Applied Pyrolysis 140: 102-111. https://doi.org/10.1016/j.jaap. 2019.02.006.

Stevenson, M.A., J.C. Faust, L.L. Andrade, F.S. Freitas, N.D. Gray, K. Tait, K.R. Hendry, R.G. Hilton, et al. 2020. Transformation of organic matter in a Barents Sea sediment profile: Coupled geochemical and microbiological processes. Philosophical Transactions of the Royal Society A: Mathematical, Physical and Engineering Sciences 378: 20200223. https://doi.org/10. 1098/rsta.2020.0223.

Tank, S.E., P.A. Raymond, R.G. Striegl, J.W. McClelland, R.M. Holmes, G.J. Fiske, and B.J. Peterson. 2012. A land-to-ocean perspective on the magnitude, source and implication of DIC flux from major Arctic rivers to the Arctic Ocean. Global Biogeochemical Cycles. https://doi.org/10.1029/2011GB004192.

Terhaar, J., J.C. Orr, C. Ethé, P. Regnier, and L. Bopp. 2019. Simulated Arctic Ocean response to doubling of riverine carbon and nutrient delivery. Global Biogeochemical Cycles 33: 1048-1070. https://doi.org/10.1029/2019GB006200.

Terhaar, J., R. Lauerwald, P. Regnier, N. Gruber, and L. Bopp. 2021. Around one third of current Arctic Ocean primary production sustained by rivers and coastal erosion. Nature Communications 12: 169. https://doi.org/10.1038/s41467-020-20470-z.

Tessin, A., C. März, M. Kedra, J. Matthiessen, N. Morata, M. Nairn, M. O'Regan, and I. Peeken. 2020. Benthic phosphorus cycling within the Eurasian marginal sea ice zone. Philosophical Transactions of the Royal Society A: Mathematical, Physical and Engineering Sciences 378: 20190358. https://doi.org/10. 1098/rsta.2019.0358.

Tiano, J.C., R. Witbaard, M.J.N. Bergman, P. van Rijswijk, A. Tramper, D. van Oevelen, and K. Soetaert. 2019. Acute impacts of bottom trawl gears on benthic metabolism and nutrient cycling. ICES Journal of Marine Science 76: 1917-1930. https:// doi.org/10.1093/icesjms/fsz060.

Tiano, J.C., E. de Borger, S. O'Flynn, C.H. Cheng, D. van Oevelen, and K. Soetaert. 2021. Physical and electrical disturbance experiments uncover potential bottom fishing impacts on benthic ecosystem functioning. Journal of Experimental Marine Biology and Ecology 545: 151628.

Trathan, P.N., M.A. Collins, S.M. Grant, M. Belchier, D.K.A. Barnes, J. Brown, and I.J. Staniland. 2014. Chapter Two-The South Georgia and the South Sandwich Islands MPA: Protecting a biodiverse oceanic island chain situated in the flow of the Antarctic Circumpolar Current. Advances in Marine Biology 69: 15-28. https://doi.org/10.1016/B978-0-12-800214-8.00002-5.

Vancoppenolle, M., L. Bopp, G. Madec, J. Dunne, T. Ilyina, P.R. Halloran, and N. Steiner. 2013. Future Arctic Ocean primary productivity from CMIP5 simulations: Uncertain outcome, but consistent mechanisms. Global Biogeochemical Cycles 27: 605-619.

Van de Velde, S., V. Van Lancker, S. Hidalgo-Martinez, W.M. Berelson, and F.J. Meysman. 2018. Anthropogenic disturbance keeps the coastal seafloor biogeochemistry in a transient state. Scientific Reports 8: 1-10.

Wassmann, P., D. Slagstad, C. Wexels Riser, and M. Reigstad. 2006a. Modelling the ecosystem dynamics of the Barents Sea including the marginal ice zone: II. Carbon flux and interannual variability. Journal of Marine Systems 59: 1-24. https://doi.org/10.1016/j. jmarsys.2005.05.006.

Wassmann, P., M. Reigstad, T. Haug, B. Rudels, M.L. Carroll, H. Hop, G.W. Gabrielsen, S. Falk-Petersen, et al. 2006b. Food webs 
and carbon flux in the Barents Sea. Progress in Oceanography 71: 232-287. https://doi.org/10.1016/j.pocean.2006.10.003.

Publisher's Note Springer Nature remains neutral with regard to jurisdictional claims in published maps and institutional affiliations.

\section{AUTHOR BIOGRAPHIES}

Christian März $(\varangle)$ is an Associate Professor at the School of Earth and Environment, University of Leeds, UK. His research interests include biogeochemical cycles and paleoenvironmental reconstructions.

Address: School of Earth and Environment, University of Leeds, Leeds LS2 9JT, UK.

e-mail: c.maerz@leeds.ac.uk

Felipe S. Freitas is a Research Associate at the School of Earth Sciences, University of Bristol, UK. He is an Oceanographer by training and applies numerical modelling to understanding marine biogeochemical cycles.

Address: School of Earth Sciences, University of Bristol, Wills Memorial Building, Queens Road, Bristol BS8 1QE, UK.

e-mail: felipe.salesdefreitas@ bristol.ac.uk

Johan C. Faust is a Postdoctoral Research Fellow at the School of Earth and Environment, University of Leeds, UK (now at MARUMCenter for Marine Environmental Sciences, University of Bremen, Germany). He uses geochemical signatures in marine sediments to unravel paleoenvironmental conditions and the carbon cycle.

Address: School of Earth and Environment, University of Leeds, Leeds LS2 9JT, UK.

Address: MARUM - Center for Marine Environmental Sciences, University of Bremen, Leobener Strasse 8, 28359 Bremen, Germany. e-mail: jfaust@marum.de

Jasmin A. Godbold is an Associate Professor at the University of Southampton, UK. Her research focusses on understanding the consequences of environmental change and human activities for benthic organisms and ecosystems.

Address: Ocean and Earth Science, National Oceanography Centre Southampton, University of Southampton, Waterfront Campus, European Way, Southampton SO14 3ZH, UK.

e-mail: j.a.godbold@soton.ac.uk

Sian F. Henley is a Lecturer in Marine Science at the University of Edinburgh, UK. Her research interests centre on biogeochemical cycling and ecosystem functioning in both polar regions, and how they are responding to and feeding back on changes in the climate and physical environment.

Address: School of GeoSciences, University of Edinburgh, James Hutton Road, Edinburgh EH9 3FE, UK.

e-mail: s.f.henley@ed.ac.uk

Allyson C. Tessin is an Assistant Professor at the Department of Geology at Kent State University in Ohio, USA. Her research interests include modern and paleo-marine biogeochemical cycling.

Address: Department of Geology, Kent State University, 221 McGilvrey Hall, 325 S. Lincoln St., Kent, OH 44242, USA.

e-mail: atessin@kent.edu

Geoffrey D. Abbott is a Reader at the School of Natural and Environmental Sciences, Newcastle University, UK. His research interests include organic biogeochemistry and carbon cycling.

Address: School of Natural and Environmental Sciences, Newcastle University, Newcastle upon Tyne NE1 7RU, UK.

e-mail: geoff.abbott@ncl.ac.uk
Ruth Airs is a Senior Analytical Chemist at Plymouth Marine Laboratory (PML). Her research evolves around developing and using improved detection and characterisation of biogeochemically relevant compounds, in particular photosynthetic pigments.

Address: Plymouth Marine Laboratory, Prospect Place, Plymouth PL1 3DH, UK.

e-mail: rairs@pml.ac.uk

Sandra Arndt is an Associate Professor at the Universite libre de Bruxelles, Belgium. She is interested in carbon and nutrient cycling across interfaces in the earth system and their feedbacks on past, present and future climate.

Address: Department of Geosciences, Environment and Society, Université libre de Bruxelles, Brussels, Av. F.Roosevelt 50, CP160/ 02, 1050 Brussels, Belgium.

e-mail: sandra.arndt@ulb.be

David K. A. Barnes is a Marine Benthic Ecologist at British Antarctic Survey, Cambridge, UK. His research interests include biodiversity, blue carbon and conservation on remote continental shelves.

Address: British Antarctic Survey, UKRI, High Cross, Maddingley Rd, Cambridge CB3 OET, UK.

e-mail: dkab@bas.ac.uk

Laura J. Grange is a Lecturer in Marine Biology at Bangor University, North Wales, UK. Her research focuses on seafloor ecological processes in both polar regions, with a particular interest in the population consequences of environmental change on the reproductive ecology and resilience of species.

Address: School of Ocean Sciences, Bangor University, Bangor, Gwynedd LL57 2DG, North Wales, UK.

e-mail: 1.grange@bangor.ac.uk

Neil D. Gray is Professor of Geomicrobiology at the School of Natural and Environmental Sciences, Newcastle University, UK. His research involves experimental approaches to link microbial biodiversity to function and geochemical conditions.

Address: School of Natural and Environmental Sciences, Newcastle University, Newcastle upon Tyne NE1 7RU, UK.

e-mail: neil.gray@ncl.ac.uk

Ian M. Head is Dean of Research and Innovation at the School of Natural and Environmental Sciences, Newcastle University, UK. His research seeks to unravel the microbial controls on biogeochemical process in natural and engineered environments.

Address: School of Natural and Environmental Sciences, Newcastle University, Newcastle upon Tyne NE1 7RU, UK.

e-mail: ian.head@ncl.ac.uk

Katharine R. Hendry is an Associate Professor at the School of Earth Sciences at the University of Bristol, UK. Her research interests include multi-disciplinary approaches to understanding biogeochemical cycling in the polar regions.

Address: School of Earth Sciences, University of Bristol, Wills Memorial Building, Queens Road, Bristol BS8 1QE, UK.

e-mail: K.Hendry@bristol.ac.uk

Robert G. Hilton is a Professor of Earth Surface Geochemistry at Durham University, UK. His research focuses on the transfers of carbon from the atmosphere to sediments, with a particular focus on how climate can amplify (or dampen) these carbon transfers.

Address: Department of Geography, Durham University, Lower Mountjoy, South Rd, Durham DH1 3LE, USA.

e-mail: r.g.hilton@durham.ac.uk 
Adam J. Reed is a Postdoctoral Researcher in Polar Benthic Ecology at the University of Southampton, UK. His interests are in reproductive ecology and life history of polar invertebrates, and the consequences of environmental change on reproductive processes.

Address: Ocean and Earth Science, National Oceanography Centre Southampton, University of Southampton, Waterfront Campus, European Way, Southampton SO14 3ZH, UK.

e-mail: adam.reed@noc.soton.ac.uk

Saskia Rühl is a Postdoctoral Researcher at the Helmholtz Zentrum Hereon in Geesthacht, Germany, and a Visiting Postdoctoral Fellow at Plymouth Marine Laboratory in Plymouth, UK. She is interested in benthic-pelagic coupling from biological, physical and biochemical perspectives.

Address: Plymouth Marine Laboratory, Prospect Place, Plymouth PL1 3DH, UK.

Address: Helmholtz Zentrum Hereon, Max-Planck-Straße 1, 21502

Geesthacht, Germany.

e-mail: saskia.ruehl@hereon.de

Martin Solan is a Professor in Marine Ecology at the University of Southampton, UK with interests in understanding biodiversity-environment interactions and the ecosystem consequences of altered diversity and environmental change.

Address: Ocean and Earth Science, National Oceanography Centre Southampton, University of Southampton, Waterfront Campus, European Way, Southampton SO14 3ZH, UK.

e-mail:m.solan@soton.ac.uk

Terri A. Souster is a Post Doctoral Researcher at The University of Tromso (UIT), Norway and a Research Fellow at The British Antarctic Survey, UK. Her research interests include benthic biodiversity, physiology and ecology of the polar regions and the implications of anthropogenic related climate change.

Address: British Antarctic Survey, UKRI, High Cross, Maddingley Rd, Cambridge CB3 0ET, UK.
Address: Department of Biosciences, Fisheries and Economics, UIT, Troms $\varnothing$, Norway.

e-mail: terrisouster@gmail.com

Mark A. Stevenson is a Postdoctoral Research Associate in Organic Geochemistry and Palaeoclimate at Durham University, UK. His research uses organic geochemical techniques to understand biogeochemical cycling and develop improved reconstructions of past environmental change.

Address: School of Natural and Environmental Sciences, Newcastle University, Newcastle upon Tyne NE1 7RU, UK.

Address: Department of Geography, Durham University, Lower Mountjoy, South Rd, Durham DH1 3LE, USA.

e-mail: mark.stevenson@durham.ac.uk

Karen Tait is a Senior Scientist at Plymouth Marine Laboratory, UK. She studies the links between microbial communities and the functions they provide in terms of carbon and nitrogen cycling within coastal and shelf sea ecosystems.

Address: Plymouth Marine Laboratory, Prospect Place, Plymouth PL1 3DH, UK.

e-mail: ktait@pml.ac.uk

James Ward is a Postgraduate Researcher at the University of Bristol. His research focusses on the biogeochemical cycling of silica in marine sediments and how sensitive these processes are to future changes in climate and the physical environment.

Address: School of Earth Sciences, University of Bristol, Wills Memorial Building, Queens Road, Bristol BS8 1QE, UK.

e-mail: JamesPJ.Ward@bristol.ac.uk

Stephen Widdicombe is Director of Science at Plymouth Marine Laboratory, Plymouth UK. His research interests include the impacts of human activity and natural disturbances on marine biodiversity. Address: Plymouth Marine Laboratory, Prospect Place, Plymouth PL1 3DH, UK.

e-mail: swi@pml.ac.uk 